\title{
PENGARUH JENIS MATA ENTRES DAN KLON TERHADAP KEBERHASILAN OKULASI DAN PERTUMBUHAN TUNAS PADA OKULASI HIJAU DI POLIBEG
}

\author{
Effect of Bud Types and Clones on Budding Success and \\ Shoot Growth of Green Budding in Polybag \\ JUNAIDI, ATMININGSIH dan Nurhawaty SIAGIAN \\ Balai Penelitian Sungei Putih, Pusat Penelitian Karet \\ PO BOX 1415 Medan 2000 \\ Email : balitsp@indosat.net.id
}

Diterima : 10 Desember 2013 / Direvisi : 3 Januari 2014 / Disetujui : 20 Februari 2014

\begin{abstract}
Currently, the propagation of rubber planting materials by direct grafting on young plants grown in the polybag has been developed widely, especially in big estates. The question often asked by planters about kind of suitable buds used for this technique. This research was aimed to determine the effect of different bud types on budding success percentage and shoot growth of green budding. The research was carried out at Experimental Garden of Sungei Putih Research Center based on Factorial Complete Randomized Design with two factors. The first factor was type of clones i.e PB 260 and IRR 118 clone and the second factor was bud types i.e. green leaf bud $(G L B)$, brown leaf bud (BLB), green scale bud (GSB) and brown scale bud (BSB). The results showed that for green budding in polybag, the most appropriate type of bud was the green scale bud (GSB). Despite the high budding success percentage (90.5\%), shoots that grew from GSB were relatively small compared with those of the other plants with the other types buds. Therefore maintenance after budding was essentially needed to enhance the growth of shoots. If the number of GSB was not enough, brown scale bud (BSB) and green leaf bud (GLB) could be used for polybag green budding, but it was not recommended to use the brown leaf bud (BLB).
\end{abstract}

Keywords : Hevea brasiliensis, green budding, bud types, budding success, shoots growth

\footnotetext{
Abstrak

Pada saat ini pengadaan bahan tanam karet dengan cara okulasi tanaman muda langsung di polibeg sedang berkembang terutama di perkebunan besar. Pertanyaan yang sering dilontarkan para pekebun adalah jenis mata
}

okulasi apa yang cocok untuk digunakan. Penelitian ini bertujuan untuk mengetahui pengaruh jenis mata okulasi terhadap persentase keberhasilan dan pertumbuhan tunas hasil okulasi hijau di polibeg. Penelitian dilaksanakan di Kebun Percobaan Balai Penelitian Sungei Putih, menggunakan Rancangan Acak Lengkap Faktorial dengan dua faktor yaitu jenis klon (PB 260 dan IRR 118) dan jenis mata okulasi yaitu mata daun hijau (MDH), mata daun coklat (MDC), mata sisik hijau (MSH) dan mata sisik coklat (MSC). Hasil penelitian menunjukkan bahwa untuk okulasi hijau dalam polibeg, jenis mata yang paling sesuai adalah mata sisik hijau (MSH). Meskipun persentase keberhasilannya tinggi $(90,5 \%)$, tunas yang tumbuh dari $\mathrm{MSH}$ relatif lebih kecil dibandingkan dengan jenis mata entres lainnya sehingga pemeliharaan setelah okulasi tumbuh sangat penting untuk meningkatkan pertumbuhan tunas. Pada kondisi MSH tidak mencukupi, okulasi hijau di polibeg dapat dilakukan dengan menggunakan mata sisik coklat (MSC) dan mata daun hijau (MDH) namun tidak dianjurkan menggunakan mata daun coklat (MDC).

Kata kunci : Hevea brasiliensis, okulasi hijau, jenis mata okulasi, persentase keberhasilan okulasi, pertumbuhan tunas.

\section{PENDAHULUAN}

Perbanyakan tanaman karet umumnya dilakukan secara vegetatif dengan okulasi yaitu suatu teknik menyatukan dua jaringan hidup tanaman (batang bawah dan mata tunas) sedemikian rupa yang kemudian tumbuh dan berkembang sebagai satu tanaman. Hartmann et al (2011) menyatakan bahwa proses penyatuan 
batang bawah dan batang atas (entres) berlangsung dalam lima tahap. Tahap pertama adalah pengaturan kambium vaskular kedua jaringan menjadi satu garis lurus, tahap kedua merupakan respons terhadap penyembuhan luka, tahap ketiga pembentukan jembatan kalus (callus bridge), tahap keempat perbaikan luka pada xylem dan phloem di jembatan kalus untuk pembentukan awal kambium, dan tahap kelima pembentukan kambium vaskular telah sempurna melewati jembatan kalus disertai pembentukan xylem dan phloem sekunder. Tahap paling vital adalah pembentukan jembatan kalus, sedangkan lama waktu yang dibutuhkan sampai penyatuan sempurna bervariasi pada setiap spesies tanaman.

Keuntungan perbanyakan tanaman secara vegetatif adalah sifat genetik tetua diturunkan melalui penggandaan kromosom sempurna selama pembelahan sel (Chanana dan Gill, 2008). Selain itu, keunggulan lainnya antara lain pelaksanaannya mudah, persentase keberhasilan tinggi dan efisien dalam penggunaan mata entres karena satu batang kayu okulasi dapat menghasilkan beberapa bahan tanam.

Berdasarkan umur batang bawah dan batang atas yang digunakan, okulasi pada tanaman karet dapat dibedakan menjadi okulasi coklat, okulasi hijau dan okulasi dini. Okulasi coklat menggunakan batang bawah berumur 7-12 bulan, mata entres daun berumur 8-12 bulan. Okulasi hijau menggunakan batang bawah berumur 4-6 bulan dengan mata sisik atau mata daun berumur 4-6 bulan, sedangkan okulasi dini menggunakan batang bawah berumur 2-3 bulan dan mata sisik berumur 3-4 bulan. Okulasi coklat umumnya dilakukan pada pembibitan batang bawah di lapangan, okulasi hijau dan dini umumnya dilakukan pada batang bawah semaian di polibeg (Siagian dan Suhendry, 2006).

Okulasi hijau di polibeg telah banyak diadopsi terutama di perkebunan besar. Di Sumatera Utara, teknik ini dikenal dengan istilah green budding, sedangkan di Jawa Tengah dikenal dengan istilah tanam benih langsung (Tabela). Siagian (2012) menyatakan perbanyakan tanaman dengan teknik okulasi hijau dalam polibeg dapat mengatasi kendala pengolahan lahan yang tidak sempurna yang menyebabkan akar tunggang bengkok atau pendek, kesulitan memperoleh areal yang rata untuk pembibitan batang bawah, dan musim biji yang tidak sesuai dengan iklim untuk pembibitan di lapangan. Selain itu, okulasi hijau dalam polibeg memiliki keuntungan yaitu mempersingkat pengadaan bahan tanam, akar terbentuk lebih sempurna, tidak memerlukan lahan yang luas dan biaya pemeliharaan yang lebih rendah dibandingkan dengan okulasi coklat (Siagian dan Bukit, 2005).

Umumnya okulasi hijau di polibeg menggunakan jenis mata sisik, namun banyak pekebun yang kurang yakin dengan mata sisik karena terbiasa menggunakan mata daun. Selain itu, jumlah mata sisik dalam satu meter kayu entres lebih sedikit dibandingkan dengan mata daun. Minimnya literatur yang menjelaskan alternatif jenis mata entres yang dapat digunakan menyebabkan banyak pekebun masih ragu mengadopsi teknik ini. Penelitian ini bertujuan untuk mengetahui pengaruh penggunaan beberapa jenis mata entres terhadap persentase keberhasilan okulasi dan pertumbuhan tunas hasil okulasi hijau di polibeg.

\section{BAHAN DAN METODE}

Penelitian dilaksanakan pada bulan Maret - September 2013 di Kebun Percobaan Balai Penelitian Sungei Putih, Pusat Penelitian Karet yang berlokasi di Galang, Deli Serdang, Sumatera Utara dengan ketinggian tempat sekitar $25 \mathrm{~m}$ di atas permukaan laut. Bahan-bahan yang digunakan dalam kegiatan ini antara lain biji karet klon PB 260, top soil, polibeg besar (ukuran 40 x $50 \mathrm{~cm}$ ), mata entres sesuai perlakuan, plastik okulasi, pupuk NPKMg 15-15-6-4, dan fungisida. Peralatan yang digunakan antara lain cangkul, kereta sorong, timbangan, pisau okulasi, kain lap, hand spayer, meteran, dan jangka sorong.

Pembibitan batang bawah dilakukan dalam polibeg besar dengan media tanam top soil. Biji karet klon PB 260 yang sudah diseleksi disemaikan dengan media pasir, kemudian kecambahnya dipindahkan ke polibeg pada stadia jarum. Kegiatan pemeliharaan yang dilakukan meliputi pengendalian gulma secara manual dua 
minggu sekali, pemupukan NPKMg 15-15-64 dengan dosis 10 gram/polibeg/bulan dan pengendalian penyakit daun dengan penyemprotan fungisida berbahan aktif Mancozeb konsentrasi $0,2 \%$ seminggu sekali.

Penelitian disusun berdasarkan Rancangan Acak Lengkap Faktorial (RALF) dengan dua faktor. Faktor pertama adalah jenis klon (PB 260 dan IRR 118). Klon PB 260 tergolong klon penghasil lateks yaitu jenis klon yang memiliki potensi produksi lateks tinggi namun produksi kayu rendah sampai sedang, sedangkan klon IRR 118 merupakan klon penghasil lateks kayu yaitu jenis klon yang mempunyai potensi produksi tinggi dan produksi kayunya juga tinggi (Daslin et al., 2008). Faktor kedua adalah jenis mata entres yang digunakan meliputi :

1. Mata daun hijau (MDH) yaitu mata tunas di ketiak daun dari jaringan yang masih muda (berwarna hijau) (Gambar 1a). Sebelum digunakan, perempelan daun dilakukan 10 hari sebelum MDH diambil.

2. Mata daun coklat (MDC) yaitu mata tunas di ketiak daun dari jaringan yang sudah tua (berwarna coklat) (Gambar 1b).

3. Mata sisik hijau (MSH) yaitu mata tunas di antara karangan daun dari jaringan yang masih muda (berwarna hijau) (Gambar 1c).

4. Mata sisik coklat (MSC) yaitu mata tunas di antara karangan daun dari jaringan yang sudah tua (berwarna coklat) (Gambar 1d).

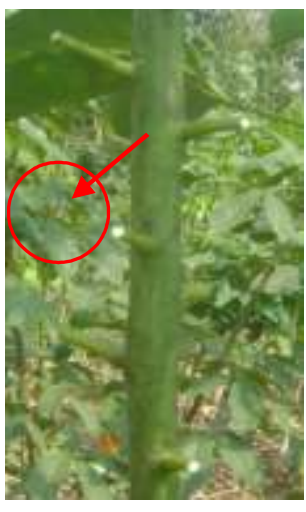

a

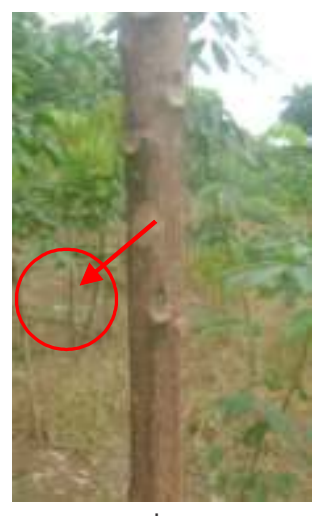

b

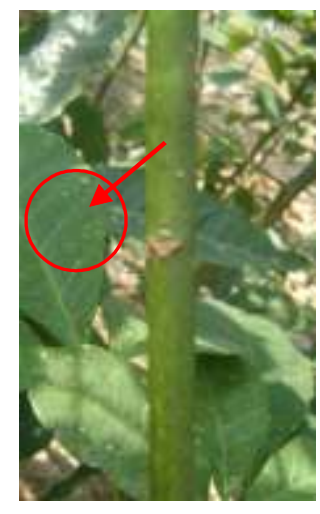

C

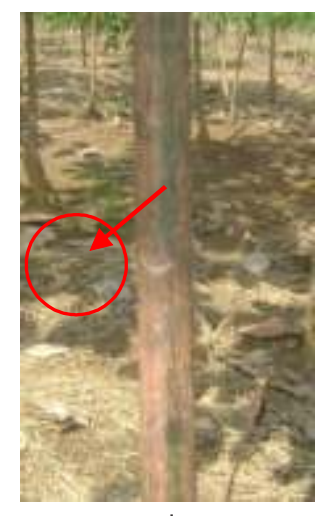

d

Gambar 1. Jenis mata entres yang digunakan dalam penelitian (mata tunas ditunjukkan tanda panah), a. Mata daun hijau (MDH), b. Mata daun coklat (MDC), c. Mata sisik hijau (MSH), dan d. Mata sisik coklat (MSC)

Figure 1. Type of buds used in this research (bud pointed with arrow mark), a. green leaf bud (GLB), b. brown leaf bud (BLB), c. green scale bud (GSB), and d. brown scale bud (BSB)

Setiap unit percobaan menggunakan 50 tanaman dan diulang sebanyak tiga kali, total tanaman yang diokulasi sebanyak 1200 tanaman. Okulasi dilakukan pada saat tanaman berumur 3,5-4 bulan setelah penanaman ke polibeg. Tiga minggu setelah okulasi, dilakukan pemeriksaan dan pembukaan perban, seminggu kemudian dilakukan penyerongan (pemotongan secara menyerong) untuk mendorong pertumbuhan tunas dari okulasi. Penyerongan pada penelitian ini dilakukan $15 \mathrm{~cm}$ dari jendela okulasi untuk menghindari pengeringan pada bekas penyerongan menjalar ke jendela okulasi. Pengamatan keberhasilan okulasi dilakukan tiga minggu setelah okulasi. Jika jendela okulasi masih hijau dan mata tunas segar, maka okulasi dinyatakan berhasil, sebaliknya jika menghitam atau busuk dinyatakan gagal. Parameter yang diamati dalam penelitian ini adalah persentase keberhasilan okulasi yang dihitung dengan persamaan sebagai berikut:

keberhasilan okulasi $=\frac{\text { Jumlah tanaman berhasil diokulasi }}{\text { Jumlah tanaman diokulasi }} \times 100 \%$

Pengamatan pertumbuhan tunas hasil okulasi meliputi panjang tunas dan diameter tunas. Panjang tunas diukur dari jendela okulasi sampai titik tumbuh tunas, diameter tunas diukur $5 \mathrm{~cm}$ dari pertautan okulasi menggunakan jangka sorong. Model linier aditif untuk rancangan percobaan yang 
digunakan adalah sebagai berikut :

$$
\mathbf{Y}_{\mathrm{ijk}}=\boldsymbol{\mu}+\boldsymbol{a}_{\mathrm{i}}+\beta_{\mathrm{j}}+(\mathbf{\alpha} \beta)_{\mathrm{ij}}+\varepsilon_{\mathrm{ijk}}
$$

Dimana :

$$
\begin{aligned}
& i \quad=1,2 \ldots, a ; \quad j=1,2, \ldots, b ; \quad k= \\
& 1,2, \ldots, r \\
& Y_{i j k}=\text { Pengamatan pada satuan }
\end{aligned}
$$

Pengolahan data dilakukan meliputi analisis sidik ragam dan uji lanjutan dengan metode Tukey pada selang kepercayaan 95\%. Dalam penelitian ini juga dilakukan pengamatan ketersediaan mata entres. Untuk masing-masing jenis entres diamati jumlah mata per meter entres pada 20 tunas entres klon PB 260 umur 2 - 8 bulan, pengamatan diulang tiga kali, total tunas entres yang diamati sebanyak 240 tunas.

\section{HASIL DAN PEMBAHASAN}

\section{Keberhasilan Okulasi}

Persentase keberhasilan okulasi hijau pada masing-masing perlakuan tertera pada Tabel 1. Dari hasil analisis statistik diketahui bahwa faktor jenis klon tidak berpengaruh nyata terhadap persentase keberhasilan okulasi, sedangkan faktor jenis mata entres dan interaksi antara klon dan jenis mata entres menunjukkan pengaruh yang signifikan terhadap persentase keberhasilan okulasi. Keberhasilan okulasi pada perlakuan MDC nyata lebih rendah dibandingkan dengan jenis mata lainnya, sedangkan MDH, MSH dan MSC berbeda tidak nyata satu sama lainnya. Persentase keberhasilan okulasi tertinggi diperoleh pada perlakuan MSH $(90,5 \%)$, terendah pada perlakuan MDC (50,9\%), sedangkan perlakuan $\mathrm{MDH}$ dan MSC masing-masing sebesar 76,5\% dan 75,5\% (Gambar 2).

Mata sisik cenderung lebih baik digunakan dibandingkan dengan mata daun. Penggunaan MSH memberikan keberhasilan okulasi lebih tinggi dibandingkan dengan MSC. Kendala yang sering dihadapi dalam penggunaan mata sisik adalah jumlah mata sisik umumnya sedikit (biasanya hanya 3-5 mata pada satu internode tunas entres) dibandingkan dengan mata daun yang lebih banyak. Sebagai alternatif, mata daun hijau (MDH) dapat digunakan untuk okulasi hijau di polibeg, sedangkan MDC tidak dianjurkan karena akan memberikan persentase keberhasilan yang rendah. Adanya perbedaan persentase keberhasilan okulasi diduga disebabkan perbedaan umur jaringan batang bawah dan mata entres. Persentase keberhasilan yang rendah pada perlakuan MDC disebabkan perbedaan umur jaringan entres dan batang bawah yang signifikan sehingga menurunkan daya gabung antar keduanya. Mata entres pada stadia yang masih muda (mata hijau) baik jenis mata daun maupun mata sisik cenderung memiliki potensi keberhasilan okulasi yang lebih tinggi dibandingkan dengan mata dewasa (coklat) pada teknik okulasi hijau di polibeg.

Hasil analisis statistik menunjukkan bahwa faktor jenis klon tidak berpengaruh signifikan terhadap persentase keberhasilan okulasi hijau, namun persentase keberhasilan pada klon PB 260 cenderung lebih tinggi dibandingkan dengan IRR 118. Rata-rata keberhasilan okulasi pada klon PB 260 adalah 76,2\% sedangkan pada IRR 118 sebesar 70,4\% (Tabel 1). Hal tersebut diduga disebabkan oleh kedekatan kekerabatan antara batang atas dan batang bawah. Pada penelitian ini digunakan batang bawah dari biji klon PB 260 sehingga memiliki kekerabatan lebih dekat dengan entres PB 260 dibandingkan dengan IRR 118. Siagian et al (2008) menyatakan bahwa batang bawah yang jagur dan mempunyai hubungan kerabat yang dekat dengan batang atas akan menghasilkan tunas yang jagur. Pada umumnya semakin jauh hubungan kekerabatan antara batang bawah dan batang atas tingkat penolakan semakin tinggi. Hal ini ditandai dengan 


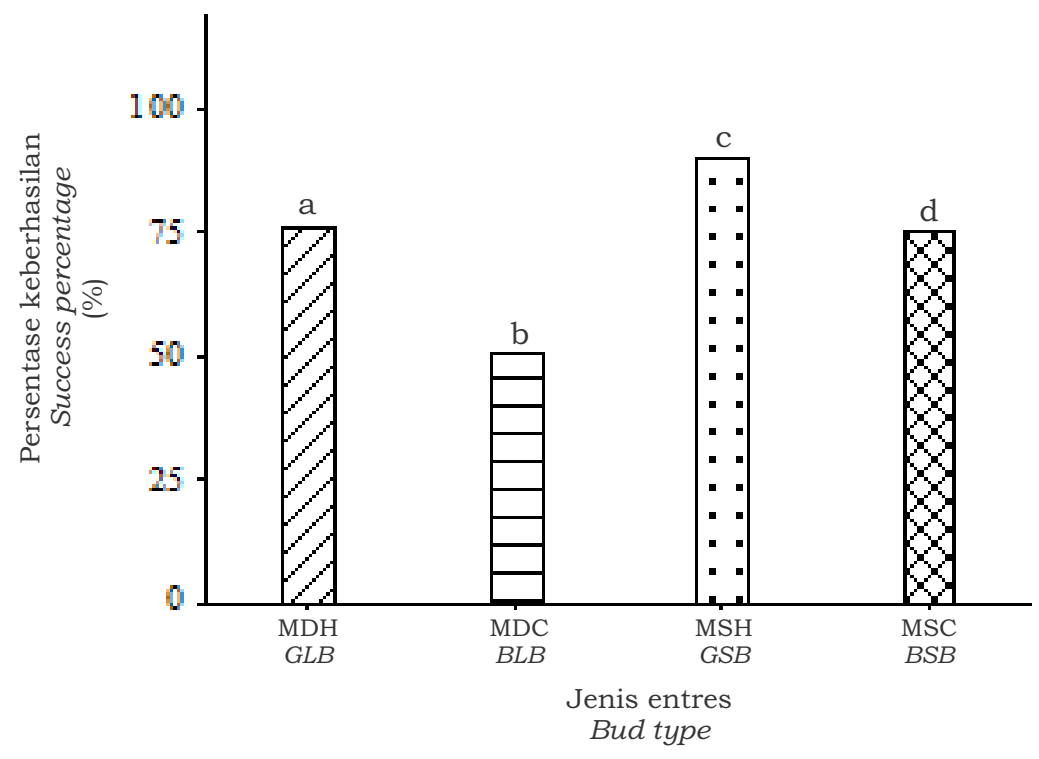

Ketrangan: Huruf yang sama menunjukkan tidak berbeda nyata pada $\mathrm{P}=0,05$ Notes: The same letter is not significantly different at $P=0.05$

Gambar 2. Pengaruh jenis mata okulasi terhadap keberhasilan okulasi Figure 2. Effect of bud types on budding success percentage

Tabel 1. Pengaruh faktor klon dan interaksi antara klon serta jenis entres terhadap keberhasilan okulasi

Table 1. Effect of clones and interaction of clones with bud types on budding success percentage

\begin{tabular}{cccc}
\hline $\begin{array}{c}\text { Klon } \\
\text { Clones }\end{array}$ & $\begin{array}{c}\text { Jenis entres } \\
\text { Bud types }\end{array}$ & $\begin{array}{c}\text { Keberhasilan okulasi } \\
\text { Budding success } \\
(\%)\end{array}$ & $\begin{array}{c}\text { Rata-rata } \\
\text { Average } \\
(\%)\end{array}$ \\
\hline PB 260 & MDH (GLB) & $71,6 \mathrm{a}$ & $76,2 \mathrm{a}$ \\
& MDC $(B L B)$ & $64,0 \mathrm{ab}$ & \\
MSH (GSB) & $87,2 \mathrm{a}$ & \\
IRR 118 & MSC (BSB) & $82,1 \mathrm{a}$ & $70,4 \mathrm{a}$ \\
& MDH (GLB) & $81,3 \mathrm{a}$ & \\
& MDC (BLB) & $37,8 \mathrm{~b}$ & \\
& MSH (GSB) & $93,7 \mathrm{a}$ & \\
& MSC (BSB) & $68,8 \mathrm{ab}$ & \\
\hline
\end{tabular}

Angka dalam kolom yang sama yang diikuti oleh huruf yang sama tidak berbeda nyata pada $\mathrm{P}=0,05$

Figures in the same column followed by the same letter are not significantly different at $P=0.05$

tingkat keberhasilan okulasi rendah, pertumbuhan tanaman lambat dan daya hasil kurang optimal.

Interaksi antara faktor klon dan jenis mata entres menunjukkan pengaruh yang signifikan terhadap keberhasilan okulasi (Tabel 1). Pada klon PB 260, keberhasilan okulasi pada perlakuan MDC nyata lebih rendah dibandingkan dengan jenis mata lainnya, sedangkan $\mathrm{MDH}, \mathrm{MSH}$ dan MSC berbeda tidak nyata di antara ketiganya. Rata-rata keberhasilan okulasi MDH, MDC, MSH dan MSC secara berturut-turut adalah $71,6 \% ; 64,0 \% ; 87,1 \%$ dan $82,1 \%$. Pada klon IRR 118 keberhasilan okulasi MDC nyata lebih rendah dibandingkan dengan MDH dan MSH tetapi berbeda tidak nyata dengan 
MSC. Perlakuan MDH, MSH dan MSC berbeda tidak nyata di antara ketiganya. Rata-rata keberhasilan okulasi MDH, MDC, MSH dan MSC masing-masing sebesar $81,3 \%, 37,8 \%, 93,7 \%$ dan $68,8 \%$.

Keuntungan dari teknik okulasi hijau di polibeg adalah kondisi daun batang bawah tidak mempengaruhi kelengketan kulit. Kulit yang masih hijau mudah lekang pada saat pembukaan jendela okulasi sejak pertumbuhan daun baru (flush) sampai berwarna hijau tua (Siagian, 2012). Oleh sebab itu, okulasi dapat dilakukan setiap saat tidak harus menunggu daun batang bawah tua. Kumar (2011) menyatakan bahwa selain keterampilan tenaga okulasi, keberhasilan okulasi ditentukan beberapa faktor terkait dengan kondisi tanaman dan lingkungan yaitu kompatibilitas batang atas dan batang bawah, suhu, musim (cuaca), umur jaringan tanaman, orientasi batang atas, pemeliharaan tanaman yang diokulasi, kelembaban tanah dan kontak antara batang atas dan batang bawah.

\section{Pertumbuhan Tunas Hasil Okulasi}

Hasil pengamatan terhadap tinggi tunas menunjukkan bahwa faktor jenis mata entres berpengaruh nyata terhadap tinggi tunas hasil okulasi pada bulan ke-1, 2 dan 3. Tunas MDC nyata lebih tinggi dibandingkan dengan jenis mata lainnya, sedangkan MDH, MSH dan MSC berbeda tidak nyata satu sama lainnya (Gambar 3). Rata-rata tinggi tunas MDH, MDC, MSH dan MSC pada bulan ke-3 berturut-turut adalah $49,89 \mathrm{~cm}, 56,67 \mathrm{~cm}, 47,90 \mathrm{~cm}$, dan 51,19 $\mathrm{cm}$.

Faktor jenis klon berpengaruh nyata terhadap tinggi tanaman pada bulan ke-3, tunas dari klon IRR 118 lebih tinggi (52,49 $\mathrm{cm})$ dibandingkan dengan klon PB 260 (50,33 cm). Pada bulan ke-1 dan ke-2, tinggi tunas kedua klon tersebut tidak berbeda nyata. Interaksi faktor klon dan jenis entres menunjukkan pengaruh nyata pada bulan ke-1, 2 dan 3. Pada klon PB 260 dan IRR 188 tunas MDC menunjukkan pertumbuhan paling tinggi sedangkan $\mathrm{MSH}$ paling rendah (Tabel 2). Pada klon PB 260, rata-rata tinggi tunas MDH, MDC, MSH dan MSC sampai dengan bulan ke-3 berturut-turut adalah $48,80 \mathrm{~cm}, 55,58 \mathrm{~cm}, 46,81 \mathrm{~cm}$ dan $50,11 \mathrm{~cm}$, sedangkan pada klon IRR 118 sebesar 50,97 $\mathrm{cm}, 57,75 \mathrm{~cm}, 48,98 \mathrm{~cm}$ dan $52,28 \mathrm{~cm}$.

Hasil pengamatan terhadap peubah diameter tunas menunjukkan bahwa faktor jenis entres memberikan pengaruh signifikan terhadap diameter tunas yang diamati. Tunas MDC menunjukkan diameter yang nyata lebih besar dibandingkan dengan

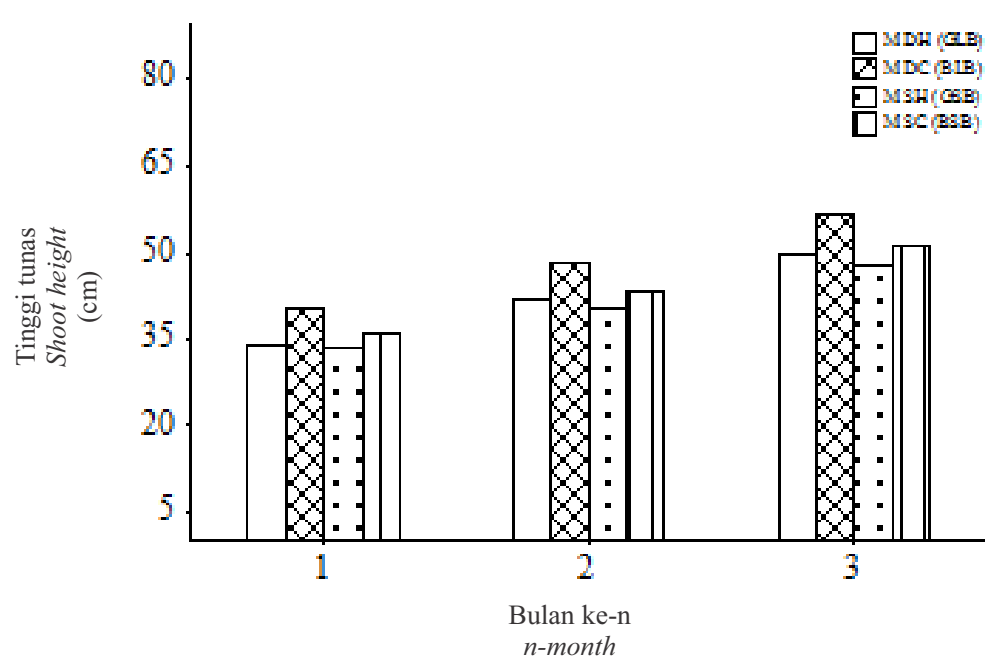

Keterangan: Huruf yang sama menunjukkan tidak berbeda nyata pada $\mathrm{P}=0,05$ Notes: The same letter is not significantly different at $P=0.05$

Gambar 3. Pengaruh jenis entres terhadap tinggi tunas Figure 3. Effect of bud types on shoot height 
Tabel 2. Tinggi tunas hasil okulasi Table 2. Shoot height of budding result

\begin{tabular}{|c|c|c|c|c|c|c|c|}
\hline \multirow[b]{2}{*}{$\begin{array}{l}\text { Klon } \\
\text { Clones }\end{array}$} & \multirow[b]{2}{*}{$\begin{array}{c}\text { Jenis entres } \\
\text { Bud types }\end{array}$} & \multicolumn{2}{|c|}{$\begin{array}{c}\text { Bulan ke-1 } \\
1^{\text {st }} \text { month } \\
\end{array}$} & \multicolumn{2}{|c|}{$\begin{array}{c}\text { Bulan ke-2 } \\
2^{\text {nd }} \text { month }\end{array}$} & \multicolumn{2}{|c|}{$\begin{array}{c}\text { Bulan ke-3 } \\
3^{r d} \text { month }\end{array}$} \\
\hline & & $\begin{array}{l}\text { Tinggi } \\
\text { tunas } \\
\text { Shoot } \\
\text { height } \\
\text { (cm) }\end{array}$ & $\begin{array}{c}\text { Rata-rata } \\
\text { Average } \\
(\mathrm{cm})\end{array}$ & $\begin{array}{c}\text { Tinggi } \\
\text { tunas } \\
\text { Shoot } \\
\text { height } \\
\text { (cm) }\end{array}$ & $\begin{array}{l}\text { Rata-rata } \\
\text { Average } \\
\text { (cm) }\end{array}$ & $\begin{array}{c}\text { Tinggi } \\
\text { tunas } \\
\text { Shoot } \\
\text { height } \\
\text { (cm) }\end{array}$ & $\begin{array}{c}\text { Rata-rata } \\
\text { Average } \\
\text { (cm) }\end{array}$ \\
\hline PB 260 & $\begin{array}{l}\text { MDH }(G L B) \\
\text { MDC }(B L B) \\
\text { MSH }(G S B) \\
\text { MSC }(B S B)\end{array}$ & $\begin{array}{l}33,62 \mathrm{bc} \\
39,63 \mathrm{ab} \\
32,72 \mathrm{c} \\
35,18 \mathrm{abc}\end{array}$ & 35,29 a & $\begin{array}{l}41,25 \mathrm{c} \\
47,64 \mathrm{ab} \\
39,80 \mathrm{c} \\
42,68 \mathrm{bc}\end{array}$ & $42,84 \mathrm{a}$ & $\begin{array}{l}48,80 \mathrm{bc} \\
55,58 \mathrm{ab} \\
46,81 \mathrm{c} \\
50,11 \mathrm{bc}\end{array}$ & $50,33 \mathrm{~b}$ \\
\hline IRR 118 & $\begin{array}{l}\text { MDH }(G L B) \\
\text { MDC }(B L B) \\
\text { MSH }(G S B) \\
\text { MSC }(B S B)\end{array}$ & $\begin{array}{l}34,82 \mathrm{abc} \\
40,83 \mathrm{a} \\
33,92 \mathrm{bc} \\
36,38 \mathrm{abc}\end{array}$ & 36,49 a & $\begin{array}{l}42,93 \mathrm{bc} \\
49,32 \mathrm{a} \\
41,48 \mathrm{c} \\
44,36 \mathrm{abc}\end{array}$ & $44,52 \mathrm{a}$ & $\begin{array}{l}50,97 \mathrm{abc} \\
57,75 \mathrm{a} \\
48,98 \mathrm{bc} \\
52,28 \mathrm{abc}\end{array}$ & 52,49 a \\
\hline
\end{tabular}

Angka dalam kolom yang sama yang diikuti oleh huruf yang sama tidak berbeda nyata pada $\mathrm{P}=0,05$ Figures in the same column followed by the same letter are not significantly different at $P=0.05$

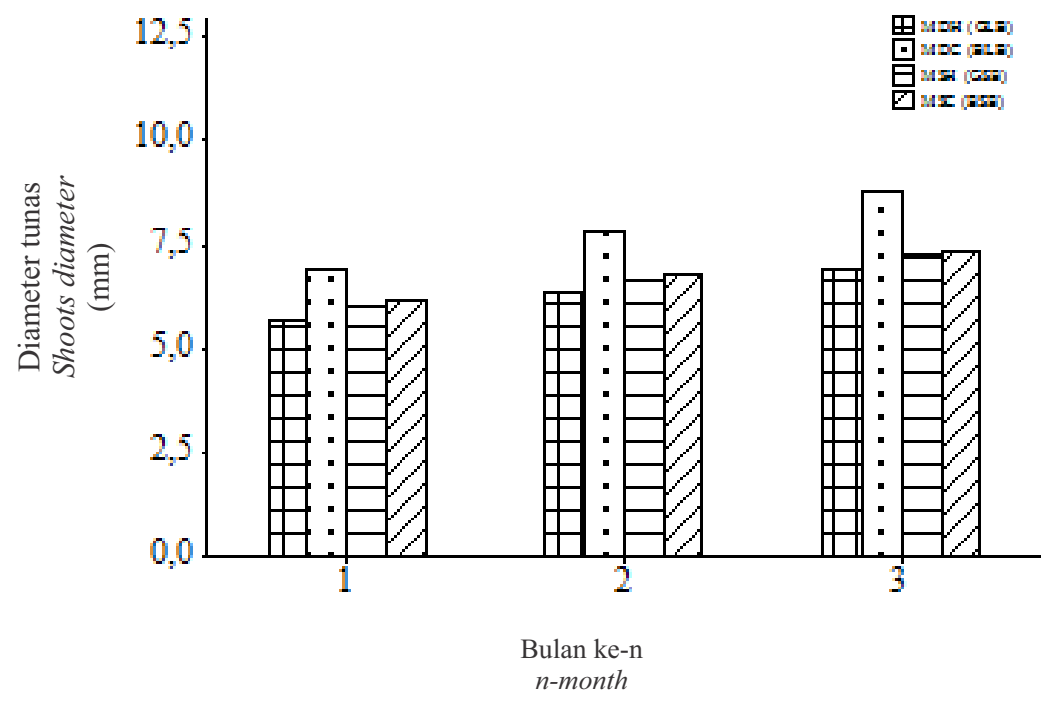

Keterangan: Huruf yang sama menunjukkan tidak berbeda nyata pada $\mathrm{P}=0,05$ Notes: The same letter is not significantly different at $P=0.05$

Gambar 4. Pengaruh jenis entres terhadap diameter tunas Figure 4. Effect of bud types on shoot diameter

jenis entres lainnya, sedangkan MDH, MSH dan MSC tidak berbeda nyata di antara ketiganya. Rata-rata diameter MDC pada bulan ke-3 adalah $8,73 \mathrm{~mm}$ sedangkan $\mathrm{MDH}, \mathrm{MSH}$ dan MSC masing-masing sebesar $6,92 \mathrm{~mm}, 7,24 \mathrm{~mm}$ dan $7,32 \mathrm{~mm}$ (Gambar 4).

Faktor jenis klon berpengaruh tidak nyata terhadap diameter tunas hasil okulasi sampai dengan bulan ke-3. Hal ini diduga disebabkan karakter pertumbuhan kedua klon ini relatif sama. Hasil pengamatan Woelan et al (2005) menunjukkan bahwa pertumbuhan lilit batang klon PB 260 dan IRR 118 di lapangan relatif sama. Interaksi antara faktor klon dan jenis mata menunjukkan pengaruh yang nyata pada bulan ke-2, sedangkan pada bulan ke-1 dan ke-3 pengaruhnya tidak signifikan (Tabel 3). 
Tabel 3. Diameter tunas hasil okulasi

Table 3. Shoots diameter of budding result

\begin{tabular}{|c|c|c|c|c|c|c|c|}
\hline \multirow[b]{2}{*}{$\begin{array}{l}\text { Klon } \\
\text { Clones }\end{array}$} & \multirow[b]{2}{*}{$\begin{array}{c}\text { Jenis entres } \\
\text { Bud types }\end{array}$} & \multicolumn{2}{|c|}{$\begin{array}{c}\text { Bulan ke-1 } \\
1^{\text {st }} \text { month }\end{array}$} & \multicolumn{2}{|c|}{$\begin{array}{l}\text { Bulan ke-2 } \\
2^{\text {nd }} \text { month }\end{array}$} & \multicolumn{2}{|c|}{$\begin{array}{l}\text { Bulan ke-3 } \\
3^{\text {rd }} \text { month }\end{array}$} \\
\hline & & $\begin{array}{c}\text { Diameter } \\
\text { tunas } \\
\text { Shoot } \\
\text { diameter } \\
(\mathrm{mm})\end{array}$ & $\begin{array}{c}\text { Rata-rata } \\
\text { Average } \\
\text { (mm) }\end{array}$ & $\begin{array}{c}\text { Diameter } \\
\text { tunas } \\
\text { Shoot } \\
\text { diameter } \\
(\mathrm{mm})\end{array}$ & $\begin{array}{c}\text { Rata-rata } \\
\text { Average } \\
(\mathrm{mm})\end{array}$ & $\begin{array}{c}\text { Diameter } \\
\text { tunas } \\
\text { Shoot } \\
\text { diameter } \\
(\mathrm{mm})\end{array}$ & $\begin{array}{c}\text { Rata-rata } \\
\text { Average } \\
\text { (mm) }\end{array}$ \\
\hline PB 260 & $\begin{array}{l}\text { MDH }(G L B) \\
\text { MDC }(B L B) \\
\text { MSH }(G S B) \\
\text { MSC }(B S B)\end{array}$ & $\begin{array}{l}5,57 \mathrm{a} \\
6,69 \mathrm{a} \\
5,92 \mathrm{a} \\
6,23 \mathrm{a}\end{array}$ & $6,10 \mathrm{a}$ & $\begin{array}{l}6,22 \mathrm{c} \\
7,73 \mathrm{ab} \\
6,54 \mathrm{abc} \\
6,75 \mathrm{abc}\end{array}$ & $6,81 \mathrm{a}$ & $\begin{array}{l}6,81 \mathrm{a} \\
8,70 \mathrm{a} \\
7,09 \mathrm{a} \\
7,20 \mathrm{a}\end{array}$ & $7,45 \mathrm{a}$ \\
\hline IRR 118 & $\begin{array}{l}\mathrm{MDH}(G L B) \\
\mathrm{MDC}(B L B) \\
\mathrm{MSH}(G S B) \\
\operatorname{MSC}(B S B)\end{array}$ & $\begin{array}{l}5,71 \mathrm{a} \\
7,11 \mathrm{a} \\
6,05 \mathrm{a} \\
6,10 \mathrm{a}\end{array}$ & $6,24 a$ & $\begin{array}{l}6,41 \mathrm{bc} \\
7,97 \mathrm{a} \\
6,75 \mathrm{abc} \\
6,80 \mathrm{abc}\end{array}$ & $6,98 \mathrm{a}$ & $\begin{array}{l}7,04 \mathrm{a} \\
8,77 \mathrm{a} \\
7,39 \mathrm{a} \\
7,43 \mathrm{a}\end{array}$ & 7,66 a \\
\hline
\end{tabular}

Angka dalam kolom yang sama yang diikuti oleh huruf yang sama tidak berbeda nyata pada $\mathrm{P}=0,05$ Figures in the same column followed by the same letter are not significantly different at $P=0.05$

Pada kedua klon yang diuji coba terdapat kecenderungan tunas MDH memiliki diameter paling kecil sedangkan MDC paling besar, meskipun secara statistik sampai dengan bulan ke-3 diameter semua perlakuan tidak berbeda nyata.

Tunas yang tumbuh dari MDC lebih jagur dibandingkan dengan jenis mata lainnya, sedangkan MDH, MSH dan MSC berbeda tidak nyata. Pertumbuhan tunas yang lebih jagur pada perlakuan MDC diduga disebabkan tingkat kematangan jaringan mata entres yang lebih baik. Sampai dengan bulan ke-3 setelah penyerongan, tunas yang tumbuh memenuhi syarat mutu bahan tanam polibeg berdasarkan Standar Nasional Indonesia (SNI) yaitu pada umur 4-6 bulan minimal memiliki tinggi tunas $20-60 \mathrm{~cm}$ dan diameter minimal 0,6 cm (Lasminingsih dan Oktavia, 2008) (Tabel 4).

Pertumbuhan yang baik salah satunya disebabkan juvenilitas batang bawah yang tinggi karena masih berumur muda. Songquan et al (1990) menduga bahwa substansi juvenilitas batang bawah ditranslokasikan ke batang atas sehingga pada derajat tertentu dapat memperbaiki juvenilitas bibit klonal yang dihasilkan. Hadi et al (2010) menyatakan bahwa penggunaan batang bawah yang lebih muda diduga memberi pengaruh perbaikan juvenilitas yang lebih baik. Selain faktor juvenilitas jaringan tanaman, pertumbuhan akar batang bawah dan pemeliharaan tanaman juga mempengaruhi pertumbuhan tunas. Pada okulasi hijau di polibeg tidak dilakukan pencabutan sebagaimana pada okulasi coklat di lapangan sehingga pertumbuhan akar tidak terganggu. Pada penelitian ini penyiraman dilakukan dengan baik sehingga pertumbuhan tunas optimal. Untuk mendapatkan pertumbuhan bibit karet yang terbaik dalam polibeg, kadar air tanah harus dipertahankan pada keadaan kapasitas lapang.

\section{Ketersediaan Mata Entres}

Hasil pengamatan terhadap jumlah mata per meter tunas yang dapat digunakan untuk okulasi hijau pada klon PB 260 menunjukkan MDC memiliki jumlah terbanyak (rata-rata $12 \mathrm{mata} / \mathrm{m}$ ) sedangkan MSC paling sedikit (rata-rata 4 mata $/ \mathrm{m}$ ), MDH dan MSH masing-masing sebanyak 9 dan 8 mata $/ \mathrm{m}$ (Gambar 5a). Untuk pembibitan polibeg dalam skala luas, jumlah mata yang diperlukan perlu dipertimbangkan. Mata sisik hijau (MSH) memberikan persentase keberhasilan yang tinggi, namun jumlah mata yang tersedia sedikit. Untuk mengatasinya, kebun kayu okulasi dapat diremajakan/dipotong dan 
Tabel 4. Standar mutu bahan tanam polibeg

Table 4. Standard quality of polybag planting material

\begin{tabular}{|c|c|c|}
\hline No. & $\begin{array}{l}\text { Tolok ukur } \\
\text { Parameters }\end{array}$ & $\begin{array}{l}\text { Persyaratan SNI } \\
\text { SNI requirements }\end{array}$ \\
\hline 1 & $\begin{array}{l}\text { Mutu genetis } \\
\text { a. Batang atas } \\
\text { b. Batang bawah }\end{array}$ & $\begin{array}{l}\text { Murni entres klon anjuran } \\
\text { Murni benih anjuran batang bawah }\end{array}$ \\
\hline 2 & $\begin{array}{l}\text { Mutu fisik } \\
\text { a. Umur bibit setelah serong } \\
\text { b. Tinggi payung } \\
\text { c. Diameter tunas } \\
\text { d. Jumlah payung daun } \\
\text { e. Warna daun }\end{array}$ & $\begin{array}{l}4-6 \text { bulan } \\
20-60 \mathrm{~cm} \\
0,6 \mathrm{~cm} \\
1-2 \text { payung } \\
\text { Hijau - hijau tua }\end{array}$ \\
\hline 3 & $\begin{array}{l}\text { Mutu fisiologis } \\
\text { a. Kesehatan }\end{array}$ & Tidak terinfeksi Jamur Akar Putih \\
\hline 4 & $\begin{array}{l}\text { Polibeg } \\
\text { a. Ukuran } \\
\text { P: Panjang } \\
\text { L: Lebar } \\
\text { b. Warna }\end{array}$ & $\begin{array}{l}40-45 \mathrm{~cm} \\
20-25 \mathrm{~cm} \\
\text { Hitam }\end{array}$ \\
\hline
\end{tabular}

Sumber (Source) : Lasminingsih dan Oktavia, 2008

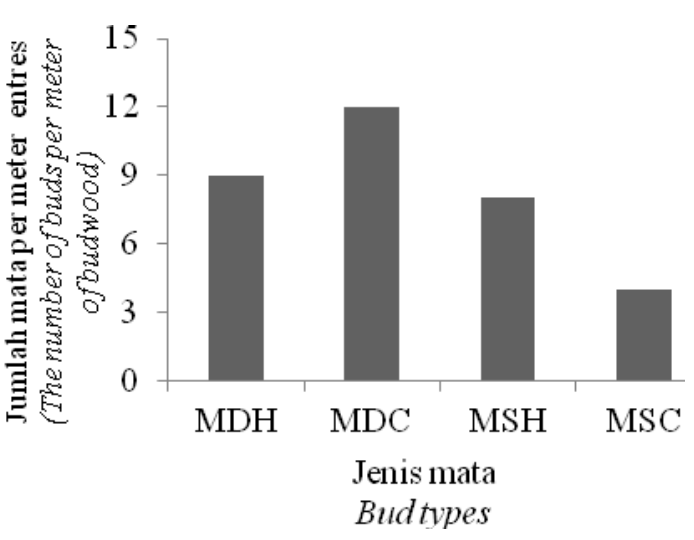

a

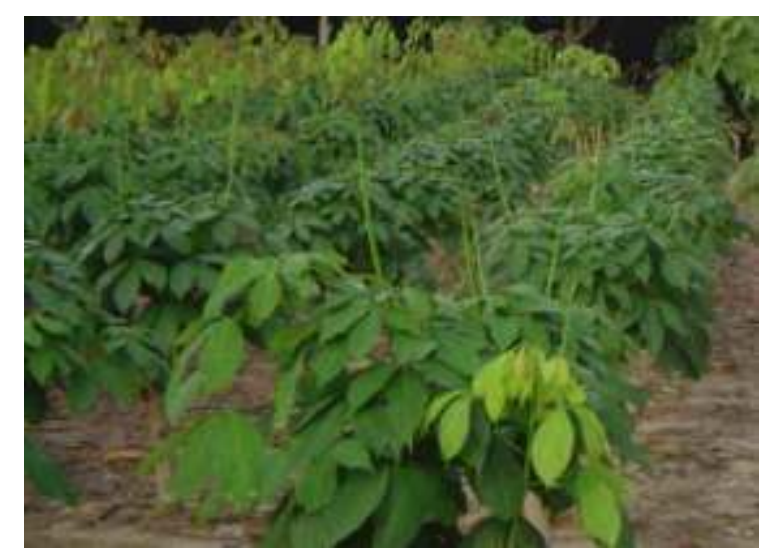

b

Gambar 5. Jumlah mata per meter kayu okulasi (a) dan kebun entres untuk mata sisik hijau (b)

Figure 5. Number of buds per meter of budwood (a) and budwood garden for green scale buds (b)

satu bulan setelah pemotongan dilakukan penjarangan dengan meninggalkan 8-10 tunas yang tumbuh/cabang (Gambar 5b). Pemanenan tunas untuk MSH dapat dilakukan 4-6 bulan setelah pemotongan. Dengan cara ini, ketersediaan MSH dapat ditingkatkan.

Selain jenis entres yang digunakan, umur kebun kayu okulasi juga dapat mempengaruhi keberhasilan okulasi. Indraty (2007) menyatakan bahwa dengan bertambahnya umur tanaman di kebun kayu okulasi, maka bertambah pula fase dewasanya, sehingga mengakibatkan mundurnya sifat-sifat unggul yang diharapkan terhadap tanaman yang dihasilkan. Siagian et al (2008) menyarankan agar cabang entres sebagai sumber mata okulasi berasal dari cabang primer dan sekunder yang diambil dari kebun kayu okulasi berumur $<10$ tahun yang diremajakan/dipangkas secara periodik. 


\section{KESIMPULAN DAN SARAN}

Untuk okulasi hijau dalam polibeg, jenis mata yang paling sesuai adalah mata sisik hijau (MSH). Pada kondisi MSH tidak mencukupi, okulasi hijau di polibeg dapat dilakukan dengan menggunakan mata sisik coklat (MSC) dan mata daun hijau (MDH) namun tidak dianjurkan menggunakan mata daun coklat (MDC). Meskipun persentase keberhasilannya tinggi, tunas yang tumbuh dari $\mathrm{MSH}$ relatif lebih kecil dibandingkan dengan jenis mata entres lainnya sehingga pemeliharaan setelah okulasi sangat penting untuk meningkatkan pertumbuhan tunas. Untuk keperluan dalam skala luas, MSH dapat dihasilkan dengan rejuvenasi kebun kayu okulasi.

Penelitian lebih lanjut diperlukan untuk mengetahui pertumbuhan tanaman belum menghasilkan (TBM) pada masingmasing bibit yang berasal dari MSH, MSC, MDH dan MDC.

\section{DAFTAR PUSTAKA}

Aidi-Daslin, S. Woelan dan I. Suhendry. 2008. Rekomendasi Penanaman Klon Karet pada Berbagai Lingkungan. Balai Penelitian Sungei Putih, Medan.

Chanana, Y. R. and M. I. S. Gill. 2008. General Horticulture: Propagation and Nursery Management. Department of Horticulture. Punjab Agricultural University, Ludhiana.

Hadi, H., L. Admojo. dan Setiono. 2010. Prospek Teknik Sambung Dini Dalam Propagasi Bibit Karet Klonal. Warta Perkaretan 29(1): 1 - 6 .

Hartmann H.T., D.E. Kester, F.T Davies, and R.L. Geneve. 2011. Plant Propagation: Principles and Practices. Chapter 11 : Principles of Grafting and Budding. Eight edition. http://aggiehorticulture.tamu.edu., diunduh tanggal 5 Januari 2014.

Indraty, I.S. 2007. Batasan Umur Kebun Kayu Okulasi Untuk Perbanyakan Tanaman Karet. Warta Perkaretan 26(2): $20-29$.
Kumar, G.N.M. 2011. Propagation of Plants by Grafting and Budding. www.coopext.colostate.edu., diunduh tanggal 5 Januari 2014.

Lasminingsih, M. dan F. Oktavia. 2008. Mutu Bahan Tanam Karet dan Sosialisasi SNI-RSNI Bibit Karet. Warta Perkaretan 27(1): 35 - 49 .

Siagian, N. dan Z. Husny. 1997. Kiat Meningkatkan Persentase Tumbuh Mata Okulasi Stump yang Dicabut Dengan Dongkrak. Warta Pusat Penelitian Karet 16(1-3): 16-20.

Siagian, N dan E. Bukit. 2005. Keuntungan Penggunaan Bibit Karet Hasil Okulasi Tanaman Muda di Polibeg. Prosiding Seminar Nasional Perbenihan III: Potret Diri Perbenihan Nasional Saat ini dan Harapannya di Tahun 2010. Yogyakarta, 10 September. Fakultas Pertanian UGM \& Forum Perbenihan DIY.: $176-187$.

Siagian, N. dan I. Suhendry. 2006. Teknologi Terkini Pengadaan Bahan Tanam Karet Unggul. Balai Penelitian Sungei Putih, Medan.

Siagian, N., A. Daslin dan H. Hadi. 2008. Potensi Produksi Klon Unggul Karet dan Upaya Pencapaiannya Melalui Penggunaan Bahan Tanam Bermutu. Prosiding Lokakarya Nasional Agribisnis Karet 2008. Yogyakarta, 20 21 Agustus. Pusat Penelitian Karet.: 95-114.

Siagian, N. 2012. Pembibitan dan Pengadaan Bahan Tanam Karet Unggul. Balai Penelitian Sungei Putih, Medan.

Songquan, L., Xienhui Y, Xiang H, and Laiyu X. 1990. Developmental Phase Change of Hevea Brasiliensis and Application of Juvenile Type Clone. Proceedings IRRDB Breeding Symposium. Kunming, $5-6$ Oct.: $26-41$

Woelan, S., Aidi-Daslin, I. Suhendry dan M. Lasminingsih. 2005. Evaluasi Keragaan Klon Karet IRR Seri 100 dan 200. Prosiding Lokakarya Nasional Pemuliaan Tanaman Karet 2005. Medan, 22 - 23 Nopember. Pusat Penelitian Karet.: 38-61. 